\title{
Impacts of Climate Change on Hydrological Regime and Water Resources Management of the Narew River in Poland
}

\author{
Łukasz Malinowski ${ }^{*}$, Iwona Skoczko' \\ ${ }^{1}$ Bialystok University of Technology, Faculty of Civil and Environmental Engineering, Department of Technology \\ and Environmental Engineering Systems, Wiejska 45A, 15-351 Białystok, Poland \\ * Corresponding author's e-mail: lukasz.malinowski66@wp.pl
}

\begin{abstract}
The amount of water required to support a river ecosystem in proper condition are of particular importance in the areas of high natural value. The hydrological threats for the protected areas are region-specific and vary from region to region. The local hydrological conditions depend largely on the temporal and spatial variations of the hydrologic cycle, of the main components and physiographic conditions on site. Future climate change is projected to have a significant impact on the hydrological regime, water resources and their quality in many parts of the world. The water-dependent ecosystems are exposed to the risk of climate change through altered precipitation and evaporation. Investigating the current climate changes and their hydrological consequences are very important for hydrological issues. This analysis may be a very important foundation for determining the causes observed in the recent period of anomalous growth - both hydrological and climatic. The aim of the research is to assess the effect of projected climate change on water resources in lowland catchment the Narew River in Poland. The hydrological reaction to climate warming and wetter conditions includes changes in flow and water level. This paper describes the directions of changes climatic and hydrological conditions and the impact of climate change on the Narew River. The data such as: daily air temperature, precipitation obtained from the Bialystok climate station located within the Narew river and hydrological data such as water flows and water states observed in water gauges were used for the analysis of climate variability and their hydrological consequences. The results show a significant decrease in winter outflows in river, as well as a delayed increase in the spring melt flow. It has also been observed that this is the initial phase of changes in maximum water levels and maximum flows.
\end{abstract}

Keywords: Narew River, water resources, ecosystem, hydrological conditions, global warming

\section{INTRODUCTION}

A climate change exerts both direct and indirect impacts on various sectors of the economy and society by affecting the biological and physical components of ecosystems, such as air, water, soil, and biodiversity. On a global scale, the climate change is becoming more and more visible, and the process is constantly aggravating. It should be assumed that in the future they will be more visible and severely noticeable for society and the economy [Piniewski, 2014]. Global warming is unquestionable, primarily due to the observation of an increase in the average global air temperature, ocean temperature, disintegration of the floating ice cover (ice melting) and the rise of the global mean sea level. Increasing the air temperature near the Earth's surface is a common phenomenon on a global scale, although its intensity indicates spatial diversity. Increasing the global air temperature is conducive to the increase in the frequency and intensity of occurrence of many climate-related phenomena, which include extreme weather events, such as heat waves, rainstorms, storms, hail, tornadoes and sandstorms [Sadowski et al., 2013].

\section{TEMPERATURE INCREASE}

Temperature is a key indicator characterizing the climate change. The last century was char- 
acterized by the variability of air temperature [Oschlies et al., 2017]. It was observed that the temperature at the Earth's surface increased by $0.74^{\circ} \mathrm{C}$ and continues to rise. Long-term observations and measurements indicate a faster increase in warming in the land areas of both hemispheres than the oceans. According to the data from the Intergovernmental Panel on Climate Change (IPCC), the temperature rise in the last two decades was twice as high above the lands than over the ocean and amounted to $0.27^{\circ} \mathrm{C}$ and $0.13^{\circ} \mathrm{C}$, respectively [IPCC, 2007]. The second half of the 20th century and the first decade of the 21 st century turned out to be a particularly warm period. The most visible changes were observed at high altitudes in spring and winter [Sadowski et al., 2013, Majewski, Walczykiewicz, 2012].

The general trend of temperature changes is conducive to the increase in the frequency of extreme precipitation, as well as expansion of the areas where drought or desertification occurs. Long-term changes in the amount of atmospheric precipitation, despite their spatial and temporal diversity, have been noted in many large areas. In the period from 1900 until 2005, the amount of precipitation increased in the northern regions of Europe, in the eastern parts of North and South America and also in the northern and central Asia. In turn, a significant decrease in the occurrence of rainfall is observed in the Mediterranean basin, in the Sahel, in the southern part of Asia and in southern Africa [Sadowski et al., 2013].

The incidence and intensity of certain extreme weather events has changed over the past 50 years, and the main changes that can be distinguished are primarily: occasional occurrence of cold nights and days as well as frosts on most land areas in medium latitudes, hot days and hot nights are more frequent. The occurrence of heat on most land areas, volatile rainfall and increase of the share of volatile rainfall is observed as well. Since 1975, a noticeable occurrence of extremely high sea level has been observed in many areas [Sadowski et al., 2013, Arcipowska, Kassenberg, 2007].

The most noticeable consequence of climate change is the global warming, resulting mainly from the human activity (combustion of fossil fuels to obtain energy, continuously increasing emission of exhaust fumes from cars, aircraft and ships, deforestation). Greenhouse gases have a total transmission of solar shortwave radiation in the range of $0.15-4.0 \mathrm{~nm}$, which heats the Earth, and also retains long-wave thermal radiation emitted from its surface. By partially reflecting the heat towards the surface of our planet, it warms it up and the rest of the radiation escapes into space. The increased content of greenhouse gases causes that the majority of long-wave radiation is directed back to the Earth's surface, and in this way are retained in the "trap" while acting in the same way as a greenhouse [James et al., 2017].

Agriculture also contributes to and experiences the effects of climate change. All agricultural crops require appropriate soils, water, heat and sunlight so that they can grow optimally. The increase in air temperature has already affected the length of the growing season in a large area in $\mathrm{Eu}-$ rope. Both flowering and harvesting cereal crops occur a few days earlier and it is expected that these changes will progress in many regions. The land designated for agricultural crops is at risk. It may be dislodged or disappear completely, leading to economic problems in countries, including lack of food. The existing extreme weather phenomena have a direct or indirect impact on a significant increase in the risk of failed harvests, also on the soil, causing a decrease in the organic matter content, which is the main factor ensuring its fertility. The direct impact is mainly a change in the atmospheric conditions for the productivity of crops, including sums of atmospheric precipitation, changes in thermal conditions, frequency and intensity of extreme phenomena. The 2004 European Environment Agency report states that compared to the 1990s, a two-fold increase in the number of climate disasters occurred, and the value of losses caused by them exceeded in 2005 the amount of up to 200 billion dollars, while at the turn of the 20th and 21st century alone, they reached several billion dollars a year [Trzpil, 2008, Tubiello et al., 2007, Olsen et al., 2011].

\section{PRECIPITATION}

Precipitation is an inseparable element of the weather and climate, which is extremely important for the economy and everyday life of people. Understanding the current state and changes in the size and structure of precipitation in the scale of the whole globe, the country as well as in the regional aspect is particularly important. Precipitation, due to the lack of continuity in time and space, is very difficult to estimate [Wibig, Jakusik, 2012]. The air pollution also affects the compo- 
sition of precipitation, which reacts with compounds introduced directly into the atmosphere. This type of rainfall is called acid rain. Very often, in some areas, the precipitation changes into sulfuric or nitric acid. The most severe effects of their impact are the contamination of water reservoirs (especially drinking water), the negative impact of vegetation. [Majewski, Walczykiewicz, 2012, Ziemniański, Ośródka, 2012, Szczygieł, 2008]. Precipitation increases the river flows and contributing to the occurrence of floods, which bring about many economic, economic and social losses. By draining agricultural areas with salt water, these areas become useless. The island of Tegua, which is part of the Vanuatu state, located in the South Pacific, experienced the effects of global warming to a great degree. In 2007, the inhabitants of this island were forced to leave their homes as a result of the flood and flooding of the island and were the first to be recognized by the United Nations as victims of global warming [IPCC, 2014].

In addition to flooding, there are other problems related to the operation and use of water. Heavy atmospheric precipitation is a consequence of the epidemic of diseases transported by water as a result of pathogens becoming active or by strong water pollution as a result of flooding sewers. In turn, reduced summer water flows can cause bacteriological and chemical risks. Higher water temperatures cause more frequent blooms of harmful algae [COM, 2009].

\section{WATER CONDITION}

Water is the basic resource of the environment; therefore, managing it according to specific rules is particularly important. The physical parameters of surface water, such as temperature, smell, taste, turbidity, transparency and color, mainly depend on the origin of water, season, climatic zone, and sewage discharged to it. The right temperature of water has a huge impact on the life of biocenosis and the course of biological, physical and chemical processes [Okruszko, Kijańska, 2009]. The water temperature is thus the predominant parameter combining climatic changes with the course of phenomena and reactions taking place in the water environment. All changes in the meteorological conditions have a direct impact on the formation of thermal conditions in all water bodies, and these in turn cause changes in the course and processes occurring in them [Miller, Frydel, 2014]. Climate changes may also affect the quality status of surface waters designated for providing people with drinking water, and even prevent the supply of healthy water, of the appropriate quality required by the regulations of the European Union and the Ministry of Health. The global warming and desertification have a major impact on the water cycle in nature. These changes relate to the amount of precipitation, water levels in rivers and lakes, snow cover supplying processes and soil moisture [Stagl et al., 2014]. They may necessitate the modification of the processes applied in water treatment technology. Limited access to water is one of the most dangerous consequences of climate change [Majewski et al., 2009].

Climate changes directly affect the intensification of anthropogenic pressures. The development of civilization caused that river valleys, lakes and wetlands are subjected to considerable abiotic and biotic loads. The most common factors that cause pressure and deterioration of water ecosystems include: water retention, river regulation, navigation, water abstraction, water metering, drainage, hydropower, tourism and recreation, point and area pollution, management of the catchment including flood plains and other activities related to the progress of civilization [Sadowski et al., 2013].

Increasing the temperature on the globe is common, especially higher in the high latitudes of the northern hemisphere. Over the last century, the average temperature in the Arctic has increased at least twice as much as on a global scale. The land areas become warm faster than the oceans. The IPCC Report presents the results of observations conducted since 1961, which show that at least to the depth of $3000 \mathrm{~m}$, the average temperature of the all-weather has risen, and that the ocean has stored over $80 \%$ of the heat that has been transferred to the climate system [Ziemiański, Ośródka, 2012]. New data analysis and satellite measurements of the central and lower temperature of the troposphere indicate warming of the same order as on the Earth's surface. In detailed hydrological systems, a greater outflow and earlier maximum spring flow of rivers with glacial and snow supply is observed, as well as an increase in rivers and lakes temperature in many areas, which has a significant impact on the thermal structure and water quality [IPCC, 2007, Okruszko, Kijańska, 2009]. 


\section{RESEARCH AREA}

The research area is the Narew River flowing through the north-eastern part of Poland and its selected tributaries. The river is one of the largest right-bank tributaries of the Vistula. It originates from the vast area of Dziki Swamp at the watershed of Narewka, Narew and Jesiołdy (tributary of Prypiat) located on the Belarusian part of the Białowieża Forest. Below the boggy area, it flows in a slightly meandering, almost natural riverbed, but on a stretch of several kilometers before the reservoir, Siemianówka takes on the character of a multi-crystal river (anastomosing). The length of the river is $484 \mathrm{~km}$, the majority of which $(448 \mathrm{~km})$ is in Poland, and the rest in Belarus [Malinowski, 2016]. After entering the territory of Poland, the river spreads into Lake Siemianowskie; then it flows from the dam in Bondary to Lake Zegrzyński, where it connects with the river Bug. After another $22 \mathrm{~km}$, in the town of Nowy Dwór Mazowiecki, Narew flows into the Vistula. As a typical lowland river, it forms vast areas of swamps, marshes and peat bogs. In the section from Suraż to Rzędziany, it belongs to the Narew National Park where it is protected. Throughout the stretch, the river flows from the north-east towards the south-west. The topography of the valley is not uniform, and the outlines of individual terraces are not clear and continuous, the edges have been blurred and distorted in the processes of erosion of side waters of tributaries. The riverbed is delicately indented, regular, with only highly meandering sections, and the longitudinal slope of the river is $0.125 \%$ [Orłow-Gozdowska, 2005].

The Narew River, along its entire length up to the Zegrze Reservoir, is unregulated, with a natural flow, forming many branches, bends and oxbow lakes. This makes the banks of the river very difficult to access. Active branches and oxbow lakes are very often reached from the main Narew riverbed. The river is characterized by a snowsupply type of regime with one clear maximum and one minimum during the year [Marcinkowski, 2017]. The largest water resources of the Narew River correspond to the early spring period, as a result of snow supply, giving in the final result the maximum values of the average monthly water levels up to the retention period, i.e. late summer and autumn. Narew is a typical lowland river, characterized by the highest flows in the period from March to April, while the lowest ones from June to October [Dembek, Okruszko, 1996]. The climatic conditions within the Narew River and its tributaries were characterized on the basis of average annual air temperatures and mean annual precipitation heights measured at the synoptic station Białystok. The hydrological conditions and their variability were determined on the basis of long-term daily measurements of the flow rate and water status in water gauge profiles: Bondary, Narew and Strękowa Góra (Figure 1).

\section{METHODS}

In this paper, the daily data of air temperature, atmospheric precipitation for the Bialystok climate station located within the Narew river and hydrological data such as flows and water levels observed in the Narew, Bondary and Strękowa Góra water level profiles were used to analyse the climate variability and their hydrological consequences. The climate data, i.e. the sum of rainfall, average air temperature and hydrological data: water levels and flows from the same research period 1981-2014 were subjected to the statistical analysis. The trend method was used to determine the tendency of variability of climate parameters over many years and to assess the shaping of flows and water levels in the catchment area under consideration. The non-parametric MannKendall statistical test was used for the study, which consists in verification of the hypothesis about the lack of trend based on the nonparametric correlation coefficient. The Mann-Kendall test analysis shows the difference between successively measured values. The newly measured value is compared to all previously measured values. The verification of this hypothesis is carried out according to the Mann-Kendall statistic defined by the formula (1):

$$
S=\sum_{k=1}^{n-1} \sum_{j=k+1}^{n} \operatorname{sgn}\left(x_{j}-x_{k}\right)
$$

where:

$$
\begin{aligned}
& \operatorname{sgn}(x)=\left\{\begin{array}{c}
+1 \text { for } x>0 \\
0 \text { for } x=0 \\
-1 \text { for } x<0
\end{array}\right. \\
& \{x 1, x 2, \ldots, x n,\}-\text { set in form of a time } \\
& \text { series }
\end{aligned}
$$

In order to determine the correlation between two variables, a correlation coefficient was determined. The nonparametric equivalent of the cor- 


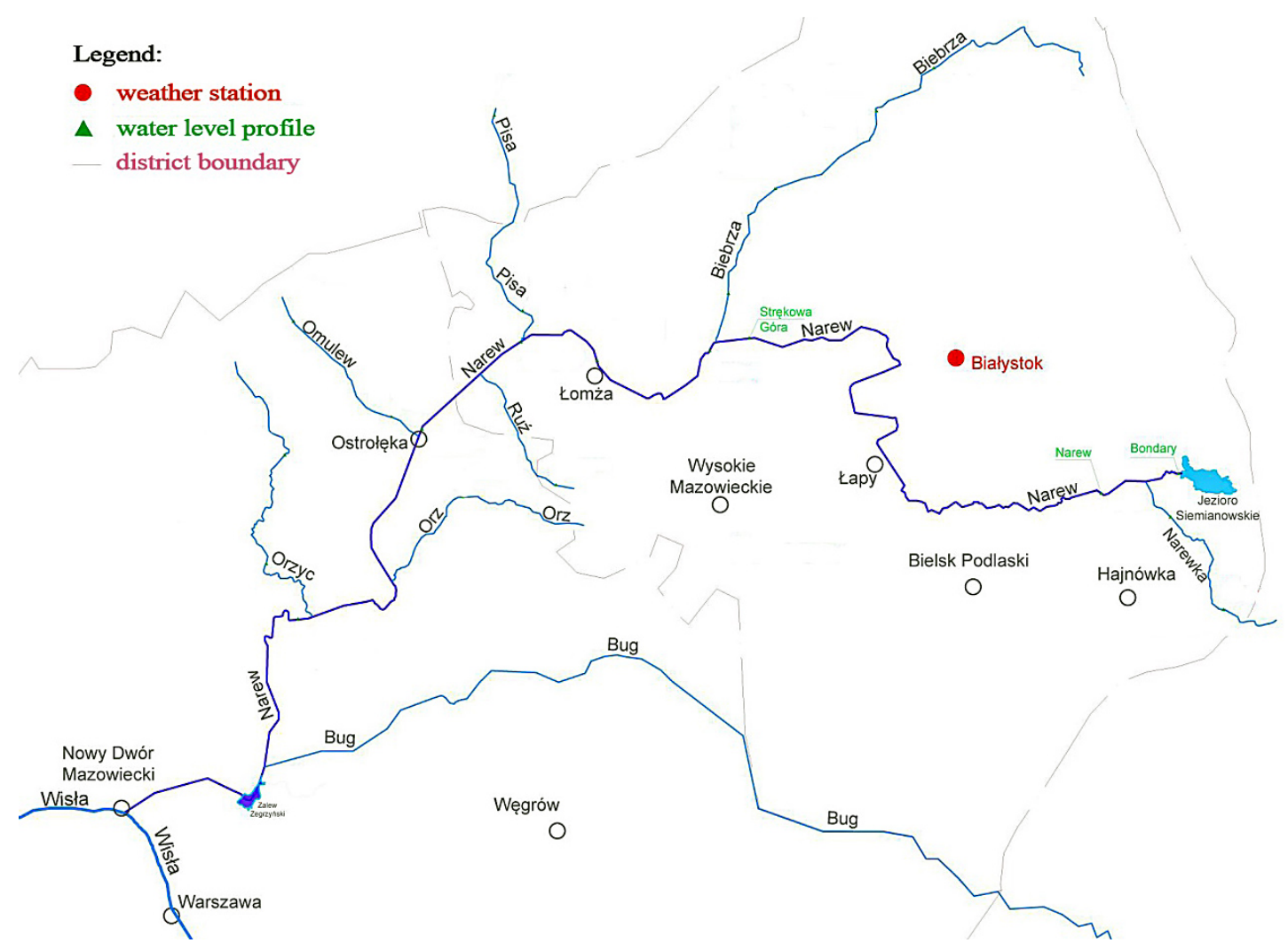

Fig. 1. The location measurement and observation stations in the study area

relation coefficient used in the Mann-Kendall test is the rank correlation coefficient in the data string and the sequence of corresponding time moments, also referred to as the Kendall tau coefficient. The values of the coefficient around zero testify to the hypothesis that there is no trend, negative values support the occurrence of a declining trend, while large positive values of the coefficient indicate the occurrence of an increasing trend. The level of significance ( $p$-value) has been determined for each test performed. In this study, a change in the significance level above 94\% (above 0.06) was assumed to be statistically significant (increasing or decreasing). The level of significance in the range of 90-94\% (0.06-0.10) indicates a near statistical significance, while only the tendency of changes was assumed to be the level of significance in the range of $75-90 \%(0.10-0.25)$. The significance level below $75 \%$ (below 0.25 ) was considered irrelevant and without a specific direction of change.

\section{Analysis of time variability of climate characteristics}

The analysis of temporal variability of climate characteristics, such as annual precipitation $(\mathrm{P})$ and mean air temperature $(\mathrm{T})$ in the year was made on the basis of statistical analysis of chronological sequences from the Białystok climate station from the measurement period 1981-2014. Demonstration of trends in changes in climate characteristics will determine the hydrological consequences of the current climate change.

As far as the statistical analysis is concerned, it can be concluded that the analysed precipitation sum from the 1981-2014 measurement period shows a growing significantly statistical trend of this characteristic on the significance level of 0.045 (p-value). The highest values were recorded in 2009 and 2010, where the average annual precipitation fluctuated in the order of 700 and 850 $\mathrm{mm}$, respectively. Currently, the growing trend of changes in precipitation sums from year to year is observed. Changes in atmospheric precipitation in the period 1981-2014 are shown in Figure 2.

In the average air temperature measured at the Bialystok climate station in the period 1981-2014, a growing, statistically significant trend - at the significance level of 0.188 (p-value) - was observed. The course of the average annual temperature in the years 1981-2014 indicates its large fluctuations from year to year (Figure 3). The year 2010 was the warmest, where the average temperature was $8.65^{\circ} \mathrm{C}$, and 1987 was the coldest, with the average temperature of $5.14^{\circ} \mathrm{C}$. 


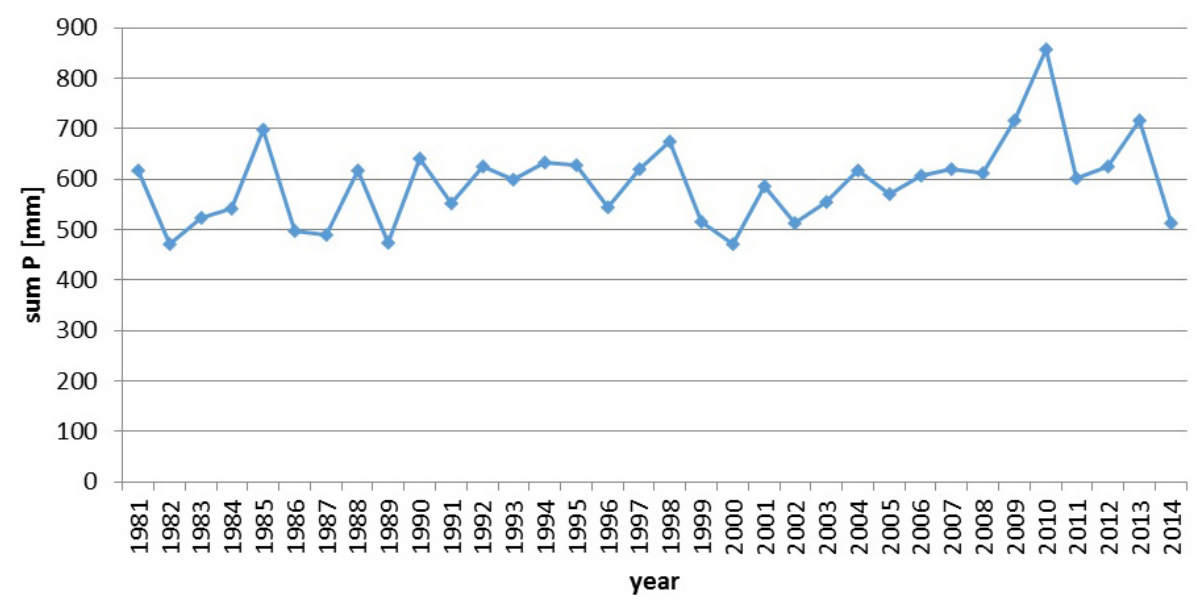

Fig. 2. The average total annual precipitation recorded at the climate station in Bialystok in the period 1981-2014

\section{Analysis of time variability of hydrological characteristics}

The Narew River is unregulated, having a natural flow character, forming many branches, bends and oxbow lakes. Its water resources and their variability along the river characterize its hydrological conditions. Therefore, the variability of maximum flows and water levels along the course of the river was analyzed on the example of three water gauge profiles - Bondary, Narew and Strękowa Góra.

The analysis of time variability of hydrological characteristics was performed on the basis of the statistical analysis of chronological sequences in individual water gauges. The variability of surface waters in the above-mentioned water level profiles was analyzed: maximum water levels $(\mathrm{H})$ and variability of maximum annual flows (Q) in the period 1981-2014.
The statistical analysis of maximum water levels in the Bondary water level profile showed a decreasing trend of statistically significant changes (Fig. 3) at the significance level of 0.046 (p-value). The lowest water level was recorded in 1992, 2003 and 2004 and reached a level of about $197 \mathrm{~cm}$. The highest water levels were observed in 1988 and 2010, where the water level reached about $270 \mathrm{~cm}$. The reason for this was the high level of precipitation in these years. In 1988, the amount of precipitation reached an average of over $600 \mathrm{~mm} /$ year, while in 2010 - about 850 $\mathrm{mm} /$ year. Similar changes were observed in the Narew and Strękowa Góra water level profiles. The declining trend of changes in water levels is statistically significant at the significance level of 0.046 and 0.031 (p-value) (Fig. 4).

The statistical analysis of maximum flows from the 1981-2014 measurement period measured in the Bondary, Narew and Strękowa Góra

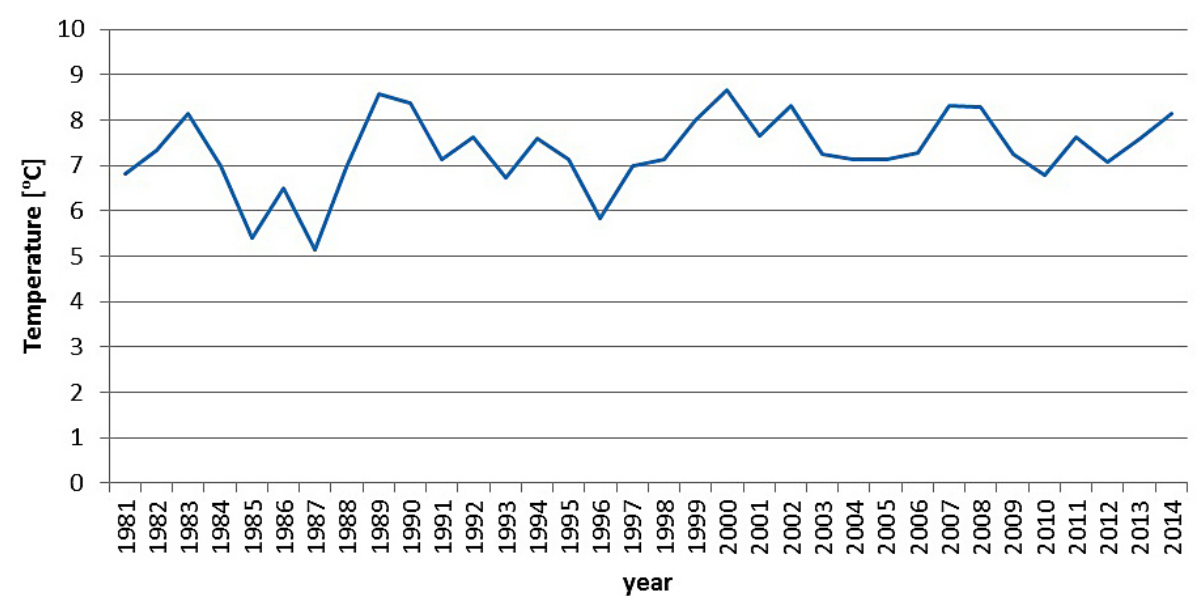

Fig. 3. The course of the average air temperature measured at the Białystok climate station in the period 1981-2014 


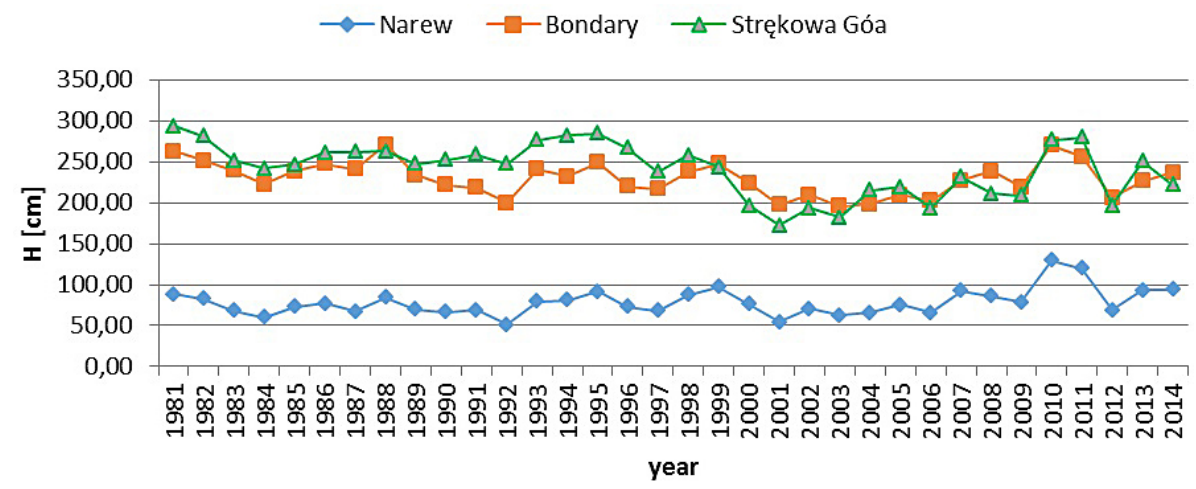

Fig. 4. Maximum annual water levels recorded in the water gauge profile: Bondary, Narew and Strękowa Góra, Narew river in the period 1981-2014

water gauge showed only descending trends statistically insignificant (Figure 5). The lowest flows were observed in the years in which low average annual amounts of precipitation were observed, such as 1992, 2003-2004. The highest flows in each water level profile were observed in 2010-2011, which were dependent primarily on the amount of atmospheric precipitation recorded in these years and the temperature course of the air during this period.

\section{CONCLUSIONS}

In recent years, the climate of Poland has changed in comparison with the climate information established on the basis of data from previous research periods -a warming has clearly occurred. The importance of climatic conditions in the modification of hydrological conditions has spatial variation due to the regional variability and en- vironmental conditions of individual catchments. Certain confirmation of climatic conditions, according to Wrzesinski [2014], can be observed in many rivers, a significant decrease in winter outflows and a delayed increase in the spring thaw in the 1950s and 1960s. Similar works were carried out by Pociask-Karteczka [2003], thus confirming the tendency of changes in water level and flows in rivers, obtained as a result of statistical analysis. In turn, Romanowicz et al. [2014] stated that the frequency changes related to the climate are very complex and also depend on the generating mechanisms.

The statistical analysis of data (especially climatic data) allows to conclude that climate warming is noticeable. The analysis of hydrological parameters such as maximum water states and flows illustrates these changes to a lesser extent. However, it is still worth paying attention to. It can be said that this constitutes the initial phase of changes in the reduction of maximum water

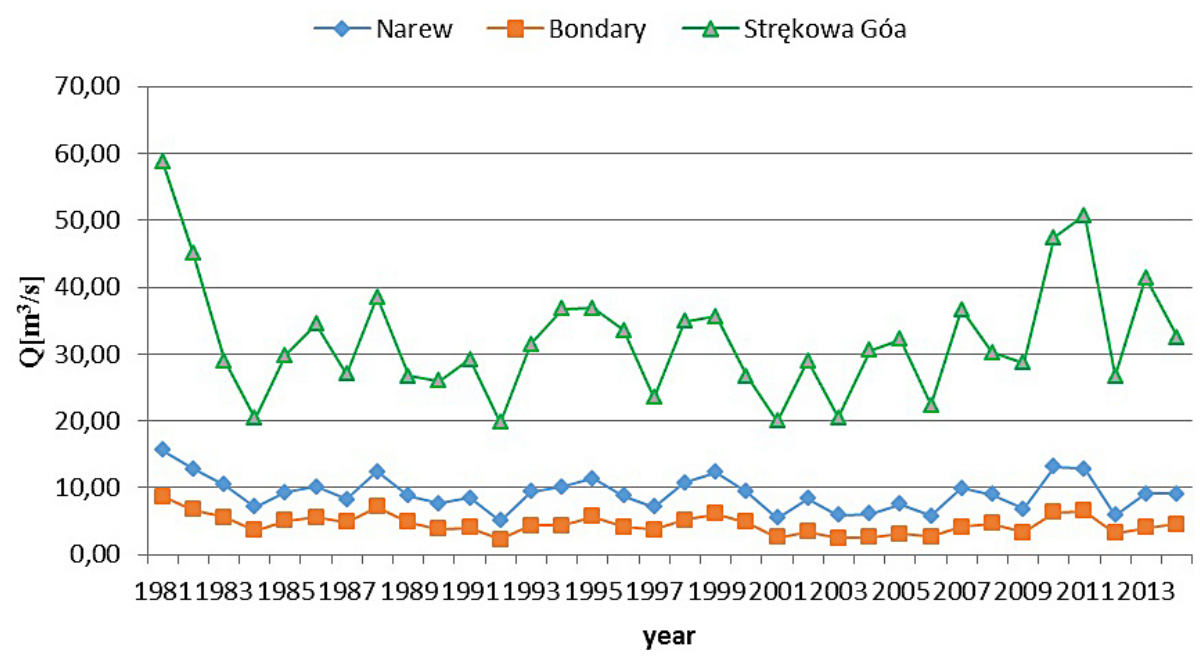

Fig. 5. Maximum annual water flows recorded in the water gauge profile: Bondary, Narew and Strękowa Góra, Narew river in the period 1981-2014 
levels and maximum flows. The study of changes in climatic conditions, i.e. observed and forecast increase in air temperature, may affect the physical, chemical and biological processes in watercourses and water reservoirs, and may lead to deterioration of water quality. The negative impact of climate change mainly includes an increase in the frequency and intensity of extreme events such as heavy rainfall, strong wind, storms, glaze, and mists.

\section{REFERENCES}

1. Arcipowska A., Kassenberg A. 2007. Small ABC ... climate protection. Institute for Sustainable Development (in Polish). Warsaw.

2. COM. 2009. Commission of the European Communities (2009)147. White paper. Adapting to climate change: Towards a European framework for action (in Polish).

3. Dembek W., Okruszko H., 1996. Economic and social issues concerning the Upper Narew Valley (in Polish). Advances of Agricultural Sciences Problem Issues. 428, 7-13.

4. IPCC 2007. Pachauri R.K. et al.. 2007. IPCC 2007: Climate change 2007. Synthetic report. Contribution of Working Groups I, II and III to the Fourth Assessment Report of the Intergovernmental Panel on Climate Change. Publisher Institute of Environmental Protection, Warsaw.

5. IPCC 2014: Climate Change 2014: Mitigation of Climate Change. Contribution of Working Group III to the Fifth Assessment Report of the Intergovernmental Panel on Climate Change [Edenhofer, O., R. Pichs-Madruga, Y. Sokona, E. Farahani, S. Kadner, K.Seyboth, A. Adler, I. Baum, S. Brunner, P. Eickemeier, B. Kriemann, J. Savolainen, S. Schlömer, C. von Stechow, T. Zwickel and J.C. Minx (Eds.)]. Cambridge University Press, Cambridge, United Kingdom and New York, NY, USA.

6. James, R., Washington, R., Schleussner, C.-F., Rogelj, J. and Conway, D. 2017. Characterizing half-a-degree difference: a review of methods for identifying regional climate responses to global warming targets. WIREs Clim Change, 8.

7. Majewski W., Stepnowski R., Wita A. 2009. Determination of the current state of the Vistula and its basin and expected changes in the medium (5 years) and long term (15-20 years) perspective - stage 1 (9.1), subtasking area: Vistula bottom, project CLIMATE, task. 9. (in Polish). IMGW-PIB, Warszawa.

8. Majewski W., Walczykiewicz T. 2012. Sustainable management of water resources and hydrotechnical infrastructure in the light of forecasted climate changes (in Polish). Institute of Meteorology and Water Management - National Research Institute. Warsaw.

9. Malinowski Ł. 2016. Master's thesis: The impact of climate change on the Narew River and its tributaries (in Polish). Białystok.

10. Marcinkowski P., Piniewski M., Kardel I., Szcześniak M., Benestad R., Srinivasan R., Ignar S., Okruszko T. 2017. Effect of Climate Change on Hydrology, Sediment and Nutrient Losses in Two Lowland Catchments in Poland. Water, 9(3).

11. Miler A.T., Frydel K. 2014. Changes in groundwater levels against the background of climatic changes in the Kaliska forest inspectorate (in Polish). Infrastructure and Ecology of Rural Areas, 11/3, 743-755.

12. Okruszko T., Kijańska M. 2009. Climate change and water management. The Institute for Sustainable Development. Warsaw.

13. Olesen J.E. et al. 2011. Impacts and adaptation of European crop production systems to climate change. European Journal of Agronomy, 34, 96-112.

14. Orłow-Gozdowska Ł. 2005. Program for protection and development of water resources in the Mazowieckie Voivodeship in the field of river restoration for bi-environmental fish. Department of Agriculture and Modernization of Rural Areas of the Marshal's Office of the Mazowieckie Voivodeship (in Polish). Warsaw.

15. Oschlies, A., Held H., Keller D., Keller K.,Mengis N.,Quaas M.,Rickels W.,Schmidt H. 2017, Indicators and metrics for the assessment of climate engineering, Earth's Future, 5, 49-58,

16. Piniewski M, Laizé CL, Acreman MC, Okruszko T, Schneider C. 2014. Effect of climate change on environmental flow indicators in the Narew Basin, Poland. Journal of Environmental Quality Environ, 43(1), 155-67.

17. Pociask-Karteczka J., Limanówka D., Nieckarz Z. 2003. Impact of North Atlantic oscillation on the flows of the Carpathian rivers (1951-2000) (in Polish). Folia Geographica, ser. Geographica Physica, 33-34, 89-104.

18. Romanowicz R.J., Nachlik E., Januchta-Szostak A., Starkel L., Kundzewicz Z.W., Byczkowski A., Kowalczak P., Żelaziński J., Radczuk L., Kowalik P., Szamałek K. 2014. Threats related to excess water (in Polish). Nauka 1, 123-148.

19. Sadowski M., Romańczak A., Dynakowska M., Kalinowska A., Siwiec E. 2013. Sixth Government Report and the first biennial report for the Conference of the Parties to the United Nations Framework Convention on Climate Change. Ministry of the Environment (in Polish). Warsaw.

20. Szczygieł L. 2008. Stopping climate change - ne- 
cessity or expensive frights? (in Polish). Energetyka, 12, 799-810.

21. Stagl J., Mayr E., Koch H., Hattermann F.F., Huang S. 2014. Effects of Climate Change on the Hydrological Cycle in Central and Eastern Europe. In: Rannow S., Neubert M. (eds) Managing Protected Areas in Central and Eastern Europe Under Climate Change. Advances in Global Change Research, 58.

22. Trzpil M. 2008. Climate change in the modern world as an element of national security (in Polish). Bezpieczeństwo narodowe. Warszawa, nr.7/8.

23. Tubiello, F.N., J.-F. Soussana, S.M. Howden, and W. Easterling. 2007. Crop and pasture response to climate change. Proc. Natl. Acad. Sci., 104, 19686-19690
24. Wibig J., Jakusik E. 2012. Climatic and oceanographic conditions in Poland and the Southern Baltic - expected changes and guidelines for the development of adaptation strategies in the national economy (in Polish). Institute of Meteorology and Water Management - National Research Institute. Warszawa

25. Wrzesiński, D. 2014. Uncertainty of the system of the outflow of rivers in Poland (in Polish). [In:] Monografie Komitetu Gospodarki Wodnej PAN, z. XX, 191-200.

26. Ziemiański M., Ośródka L. 2012. Climate change and monitoring and forecasting the condition of the atmospheric environment (in Polish). Institute of Meteorology and Water Management - National Research Institute. Warsaw. 